\title{
LEI SECA NO PERÍODO DO VESTIBULAR E SUA RELAÇÃO COM AS POLÍTICAS PÚBLICAS DE LAZER
}

Recebido em: 10/06/2009

Aceito em: 26/02/2010

\author{
Flávia Évelin Bandeira Lima ${ }^{1}$ \\ Luis Miguel Martins ${ }^{2}$ \\ Marcelo Kuhne de Oliveira Sponchiado ${ }^{3}$ \\ Giuliano Gomes de Assis Pimentel ${ }^{4}$ \\ Universidade Estadual de Maringá - UEM \\ Maringá - PR - Brasil
}

RESUMO: A Universidade Estadual de Maringá (UEM) possui uma população acadêmica de aproximadamente 24 mil estudantes. Durante o vestibular, a cidade chega a receber cerca de 20 mil candidatos, os quais ficam hospedados próximos à universidade. Após as provas, candidatos e acadêmicos se aglomeram em determinados bares e lanchonetes para se confraternizarem em torno de comida, bebida, paquera e som alto. Essa festa dos jovens causou transtornos ao descanso dos moradores, que, por sua vez, obtiveram a proibição do consumo de bebida em lei municipal. O presente trabalho visa compreender a Lei Seca como uma (falta de) política pública de lazer para a juventude, tendo como norte a opinião da população sobre a festa. Descobriu-se que há entre os moradores e estudantes soluções para os conflitos gerados pela festa. Dessa forma, concluiu-se que a lei foi prematura, revelando a dificuldade do poder público em dialogar com os jovens e a deficiência de políticas públicas voltadas ao lazer dos mesmos.

PALAVRAS-CHAVE: Políticas Públicas. Atividade de Lazer. Adolescente.

\section{DRY LAW IN THE PERIOD OF VESTIBULAR AND ITS RELATION WITH PUBLIC POLICY OF LEISURE}

ABSTRACT: The State University of Maringá (UEM) has an academic population of approximately 24 thousand students, and during the test to enter of university, the city gets to receive around 20 thousand candidates who are staying around the university. Thus the bars, restaurants and cafeterias serving needs of visitors and serve as a meeting point between students and academics. This work aims to understand the conflict between residents of Zone

\footnotetext{
${ }^{1}$ Graduanda em Educação Física pela UEM.

${ }^{2}$ Graduando em Educação Física pela UEM.

${ }^{3}$ Graduando em Educação Física pela UEM.

${ }^{4}$ Professor Doutor em Lazer e Recreação do Departamento de Educação Física da Universidade Estadual de Maringá.

Licere, Belo Horizonte, v.13, n.1, mar./2010 
7 and the students, because of the festival, and check for Public Policy Leisure for young people and the impact of the Dry Law, endorsed by the Executive of Maringá, for the period the entrance exam. Thus, the end of the study, we found the main problems and demands of residents and students of the district, the deficiency of public policies aimed at leisure.

KEYWORDS: Public Policies. Leisure Activities. Adolescent.

\section{INTRODUÇÃO}

Por meio de festas, as pessoas, em diferentes culturas, têm possibilidade de vivenciar o lazer, uma vez que ele se realiza no tempo livre, partindo da relação de cada indivíduo com outros. O objeto de estudo dessa pesquisa é a "festa" dos estudantes durante o vestibular da Universidade Estadual de Maringá, levantando os problemas causados por esse lazer e qual a sua relação com as políticas públicas. Para isso, fazem-se necessários alguns entendimentos sobre a questão da ocupação urbana e do que se entende por lazer.

O tempo livre não pode ser considerado como pura perda ou desperdício, mas sim como um momento de produção social. Moesch (2003) considera o tempo livre aquele que possa ser escolhido livremente, havendo também uma participação efetiva sem que haja prejuízo à qualidade de vida e abuso dos meio natural e cultural, onde quer que ele seja praticado.

Dessa maneira, pode-se compreender que a festa é uma forma de exposição e contato com valores, crenças, danças, religiosidade e folguedos, além do reconhecimento entre as pessoas e os elementos que as distinguem umas das outras. Esses elementos, chamados de identidade cultural, resgatam a auto-estima de um povo (LIMA, 2004).

Já com relação à ocupação dos espaços urbanos, observa-se que é feita de forma desordenada, sob os interesses do capital e de seu segmento imobiliário, acabou por determinar o perfil físico-paisagístico das cidades. Em menos de três décadas, o país sofreu uma mudança significativa na sua dinâmica populacional, passando de uma sociedade de base rural para uma eminente urbana (MAIA, OLIVEIRA, LIMA, 2007). 
A situação é agravada quando se tratam de espaços e equipamentos de lazer, pela falta de "ressonância social" da problemática (MARCELLINO, 1996), pois, observando-se os levantamentos quantitativos, o lazer não é normalmente entendido como essencial e, portanto, os espaços e equipamentos de lazer não costumam merecer a atenção necessária, nem lhes é atribuída à importância real em uma política de administração urbana.

Segundo Marcellino (1996), é possível ainda constatar, principalmente, a centralização de equipamentos específicos (teatros, cinemas, bibliotecas, entre outros), ou sua localização em espaços públicos segmentados, o ar de "santuário" de que ainda se revestem um bom número deles e as dificuldades para utilização de equipamentos não específicos - o próprio lar, bares, escolas.

O urbanismo moderno atribuiu às cidades quatro funções: lazer, moradia, trabalho e circulação. Dessas, três ficaram confinadas e localizadas em espaços privados, cada vez mais circunscritos e homogêneos, cabendo à dimensão pública a quarta função (ROLNIK, 2004). Contudo, os grupos sociais de classes sociais menos abastadas da cidade tornam públicas as quatro funções acima citadas.

Diferentemente do lazer, que pode ser desfrutado tanto nos espaços públicos quanto privados, a circulação tem unicamente âmbito público, pois se faz por meio de todas as classes sociais. Mas, como os investimentos em equipamentos de lazer são feitos, na maior parte das vezes, pela iniciativa privada, o espaço público passa a possuir equipamentos de qualidade inferior, que pode ser explicada pela negligência do poder público relativa a essa questão; e também porque há uma crescente privatização dos espaços de convivência social em favor das classes mais altas. Com a substituição do bairro pelo condomínio fechado, os espaços públicos de lazer pelos clubes e os centros de entretenimento e as ruas pelos shoppings centers (CARVALHO, 2006). 
A própria valorização da rua enquanto espaço de lazer é uma questão para o poder público. Nas cidades maiores, há poucos espaços públicos vazios, falta de segurança nos equipamentos públicos de lazer e no transporte até eles. O sistema de transporte público, por sua vez, é bastante limitado. Essas condições favorecem um lazer restrito, de consumo rápido e possibilidades ínfimas, se comparado as suas potencialidades, dificilmente haverá satisfação e, menos ainda, desenvolvimento pessoal e social do praticante; não se observa uma preocupação em facilitar a convivência e a troca de experiências entre pessoas, assim como o seu acesso aos equipamentos, ou proporcionar conforto e segurança no deslocamento pela cidade.

Um exemplo dessa evolução urbanística é a cidade de Maringá, com 325.968 mil habitantes (IBGE, 2001). Embora seja uma cidade planejada, apresenta alguns problemas em função da má ocupação de seu espaço urbano. Já em termos econômicos, Maringá, fundada em 1947, caracteriza-se por desempenhar diversos papéis urbanos especializados como na indústria, comércio, principalmente no ramo alimentício e de vestuário, e também outros que estão em constante desenvolvimento.

Segundo dados divulgados pela Revista Suma Econômica (2004, p. 14-18) - que se fundamentou nas bases estatísticas do IBGE e nos valores econômicos nacionais dos últimos 50 anos - a cidade de Maringá e sua microrregião foram apontadas como o $23^{\circ}$ maior potencial de crescimento econômico no período de 2004 a 2010, abaixo, dentro do estado do Paraná, de Londrina $\left(13^{\circ}\right)$ e Cascavel $\left(20^{\circ}\right)$ e acima de Curitiba $\left(29^{\circ}\right)$ e Ponta Grossa $\left(43^{\circ}\right)$, dentre os 50 municípios ou microrregiões de maior potencial no Brasil.

Nesse contexto, torna-se importante ressaltar a evolução do número de Instituições de Ensino Superior (IES) públicas e privadas no Brasil, em especial no município de Maringá, considerando que elas trouxeram mudanças geoeconômicas no espaço urbano e interurbano, 
desencadeando significativas transformações conjunturais na economia, no mercado imobiliário, no setor de serviços e, enfim, na (re) produção dessa cidade.

Com a implantação dessas IES, Maringá tem um aumento considerável de sua população, principalmente no período de ano letivo, e teve aumento de bairros, como por exemplo, o Jardim Universitário localizado na zona 7. A implantação das IES pode ser dividida em dois períodos distintos: no primeiro, a expansão do setor público nas décadas de 60, 70 e 80, quando foi instituída a Universidade Estadual de Maringá (UEM), e o segundo período, com a expansão do setor privado, a partir de 1990 (LUZ, 1997).

O aumento do número de IES e a constante ampliação da quantidade de cursos atraíram vestibulandos e acadêmicos de diversas cidades e estados do Brasil, que, além de aumentarem a população da cidade, utilizam os serviços, as infra-estruturas, o comércio e as áreas de lazer, desencadeando transformações econômicas, sociais, políticas e geográficas que são materializadas no espaço urbano. Embora sejam materiais, as configurações, os objetos e as infra-estruturas são resultados das abstrações, dos planejamentos e das políticas, que promovem uma dinâmica no espaço urbano, configurando um processo e não apenas um espaço físico, materializado e apolítico (MOTA, 2006).

A maior e mais significativa IES da cidade é a UEM, cujo vestibular de inverno de 2008, segundo a Associação Comercial e Industrial de Maringá (ACIM), teve 22.410 inscritos, dos quais 1.416 não fizeram a prova de conhecimentos gerais no primeiro dia de exame. Alguns acreditam que esse número de abstenções deve-se à Lei Seca que entrou em vigor na cidade na semana que antecedeu o vestibular (ACIM, 2008). Por outro lado, segundo o professor Doherty Andrade, presidente da Comissão Central do Vestibular Unificado (CVU), o índice de faltosos é considerado baixo, mesmo que ele tenha sido um pouco maior em Maringá, quando comparado ao de outras cidades. Comparando ao ano passado, o índice de faltas, no geral, foi de aproximadamente 12\% (ACIM, 2008). 
A Lei Seca foi aprovada com o argumento de que, depois de conviver muitos anos com os vestibulares tumultuados, a cidade de Maringá está tentando diminuir os problemas durante esse período. A Lei Municipal $n^{\circ} 8054 / 2008$, proíbe a venda e consumo de bebidas alcoólicas em torno da UEM, no período de realização de vestibulares, sendo aprovada pela Câmara Municipal de Maringá, estado do Paraná e sancionada pelo Prefeito Municipal, dispondo que:

Art. 1..$^{\circ}$ Ficam proibidos a venda e o consumo de bebidas alcoólicas, nos estabelecimentos comerciais de e por autônomos, no entorno da Universidade Estadual de Maringá, no período de realização de vestibulares.

Art. 2. ${ }^{\circ}$ As penas impostas ao descumprimento da presente Lei, nos termos da Lei Complementar n.413/2001, artigo 21 são:

I - para estabelecimento comercial:

Multa de R\$ 5.000,00 (cinco mil reais);

II - para vendedor autônomo: Multa de $\mathrm{R} \$ 500,00$ (quinhentos reais) e apreensão da mercadoria.

(DIÁRIO OFICIAL da Prefeitura do Município de Maringá, 2008).

Essa lei apresentou grande repercussão na sociedade maringaense. Diante desse fato, fazem-se necessários alguns questionamentos: a festa que ocorre nos dias do vestibular é um problema para a vizinhança? Ou será que a festa é um elemento que compõe o espírito universitário do bairro, já que impulsiona o comércio, gerando renda? Considerando que a Zona 7 é um bairro majoritariamente universitário, será que todos estão incomodados com o barulho? Há necessidade de atuação da polícia, durante os dias de vestibular, pensando ser a festa uma forma de lazer? E será que essas festas não trazem pontos positivos para que os vestibulandos possam se confraternizar?

Dada essa problemática, o estudo analisou a percepção de moradores e estudantes sobre a festa no vestibular e a Lei $\mathrm{n}^{\circ}$ 8054/2008, tendo como eixo as políticas públicas de lazer. Para tanto, foram entrevistados 132 moradores ao redor da universidade pelo período de um mês. As entrevistas foram tabuladas a partir de categorias retiradas das falas, sendo utilizadas como fontes complementares documentos tais como jornais, blogs e diário oficial. 
Conforme se expressou Wil Scaliante, do Movimento Acorda Maringá (2008), para a criação da lei foi necessário um movimento e "os incomodados com a suposta 'baderna' promovida por estudantes", os moradores da Zona 7, levaram um abaixo assinado à sessão do Legislativo, cobrando fiscalização da prefeitura. O documento se tornou um requerimento, tendo a vereadora Marly Martin (DEM) como autora. Interessante notar que a Zona 7, ou Jardim Universitário, é o local onde existe a maior concentração de estudantes e o maior questionamento é se realmente a maioria dos moradores está incomodada com as festas realizadas nos dias de vestibular.

Scaliante (2008) concorda ainda com a nota emitida pelo Diretório Central dos Estudantes (DCE) da UEM, argumentando que a Universidade tem 30 anos de funcionamento no mesmo local e que, durante esse tempo, sempre houve confraternizações em repúblicas e em bares do bairro. Sabendo ser um bairro estudantil, como já dito, algumas famílias e estudantes buscam locais mais distantes, onde teria maior tranqüilidade para morar: "O que realmente querem, é acabar com o espírito universitário do bairro" afirma Scaliante.

Ainda com relação às repercussões da implantação da Lei Seca, em reportagem da Rpc notícias, (PORTAL RPC, 2008), foi apontado o prejuízo que os comerciantes tiveram, sendo que alguns nem abriram o estabelecimento para que não houvesse maiores perdas. Lanchonetes, padarias, bares e ruas tiveram seu público reduzido.

Voltando ao tema das festas, nos dias de vestibular, por sua importância social, pode ser lazer, folclore e cultura. Segundo Martoni e Schwartz (2006), o lazer exerce uma contingência importante na vida das pessoas, apesar de ser entendido, no espaço de vida dentro do âmbito educacional, como preconceituoso e estigmatizante. Mesmo assim, sabe-se que o lazer foi por muito tempo considerado algo que desencadeia mudanças no ser humano em todos os sentidos e aspectos relacionados, até mesmo, com a ordem moral, cultural e social. 
A festa pode, pois, ser concebida sob diferentes visões, como: a do folião, a do morador do local onde ela ocorre, a do administrador, a do pesquisador ou a do turista, cada um desses olhares revela diferentes significados (ROSA, 2002). Dessa maneira, sabe-se que é comum para a população pensar que as festas universitárias são lugares onde há uma concentração de venda de drogas e práticas ilícitas. Contudo, é também um lugar de interação entre aqueles que almejam uma vaga na UEM e aqueles que já compõem o corpo discente dessa universidade.

Vista por um viés cultural, a festa pode ser considerada como um legado de um povo e elemento de registro da memória coletiva e individual, contribuindo para a formação do sentimento das pessoas. Há possibilidade de se exporem os elementos de identidade mais significativos de uma determinada cultura e a avaliação ou contato com o passado e o presente, que são importantes, em muitos aspectos (LIMA, 2004).

Lanternari $^{5}$ (1989, apud FERREIRA, 2001) relata que a festa estabelece uma relação complexa com a realidade, pois acrescenta sentido àquilo que, no cotidiano, é percebido como descontinuidade, relacionado a seu contexto, pois permite um acréscimo de sentido (valor de construção da identidade ameaçada) e um aumento da percepção das relações sociais (a importância do sentimento de pertencer à determinada comunidade). Ainda com relação à festa, Rosa explica que:

A festa é, assim, associada a motivações, valores e interesses diversos. Efêmera ou duradoura, surpresa ou planejada [...] é uma celebração que geralmente se atrela a datas e acontecimentos comemorativos [...]. A motivação, individual ou coletiva, singular ou plural, pode ser associada a valores relacionados à agricultura [...] ao folclore [...], entre outros (ROSA, 2002, p. 18).

Reiterando, a festa é uma forma de lazer e para tanto, fazem-se necessárias algumas considerações acerca desse. O lazer, segundo Muller e DaCosta, (2002), se dá no tempo

\footnotetext{
${ }^{5}$ LANTERNARI, Vittorio. Festa,carisma, apocallisse. Palermo: Sellerio, 1989.
} 
disponível das pessoas, dentro de uma experiência de acordo com a atitude adotada de forma gratuita e rica de ludicidade, apresentando as seguintes funções: de diversão pura, na qual o eu e a experiência vivida são um só; de diversão, ou de recuperação das energias gastas em atividades cotidianas (não só o lazer como descaso, mas também como compensação do trabalho); e de desenvolvimento integral da pessoa e da sociedade, ou seja, da evolução do ser dentro e com a comunidade.

Além das funções acima, o lazer possui característica particular de gratuidade e de liberdade, que faz com que as pessoas o vejam como algo prazeroso, sem compromisso e praticado em um tempo livre, ausente de preocupações. Esses elementos, como complementam Santini (1993) e Leite (1995), se inserem no termo "lazer", como algo que tende a um significado de ausência ou afrouxamento de diferentes regras, dependência, ausência de obrigações de repressão ou censura, ou seja, livre.

O espaço de lazer possui uma importante relação com o convívio social, por ser um espaço de encontro, por meio do qual pode acontecer uma conscientização, ou seja, o despertar da pessoa a fim de descobrir que os espaços urbanos equipados e conservados para o lazer são indispensáveis para o bem estar de todos. Assim, é de grande relevância observar alguns exemplos de festas universitárias que acontecem em outras cidades brasileiras, a fim de verificar possíveis diferenças e semelhanças com as ocorridas em Maringá.

Na cidade de Viçosa em Minas Gerais existem diversas festas tradicionais organizadas por estudantes, sendo uma delas a chamada "Nico Lopes". Essa festa foi organizada por estudantes em meados dos anos 40/50 e todo ano, eles iam até o bar Nico Lopes, onde bebiam exageradamente e voltavam para a UFV, protestando sempre de modo caricato e engraçado. Em 2002, a festa foi uma das mais animadas, com trio elétrico, muita alegria e contestação social. Em 2006, a festa teve um concurso de bandas, todos os dias em um bar diferente, com 
uma marcha da bateria de uma escola de samba. Bem diferente dos outros anos, nos quais a festa tomava o campus e envolvia toda a comunidade universitária (PEREIRA et al., 2008).

Viçosa tem aproximadamente 80 mil habitantes e desses, 12 mil são estudantes e as festas organizadas por eles são suas principais atrações de lazer. A UFV, desde sua fundação, vem acumulando uma grande experiência e tradição no ensino, pesquisa e extensão, atraindo estudantes dos mais variados estados do país. Desse modo, a vida econômica, social e política do município dependem consideravelmente dessa instituição, que proporciona grande parte do sustento da cidade (SOUZA, 2005).

Na cidade de Ouro Preto, também no estado de Minas Gerais, há um dos carnavais mais conhecidos do Brasil. Turistas e moradores se divertem nas ladeiras ao som dos blocos carnavalescos independentes e estudantis. A festa se deve principalmente ao grande número de repúblicas de estudantes existentes na cidade, que nessa época do ano oferecem hospedagem para turistas de diversas partes do mundo. Além dos shows, o carnaval de Ouro Preto conta com 37 blocos carnavalescos, que desfilam, em horários alternados, pelo centro histórico da cidade (ASSIS, s/d).

Essas duas festas, bastante tradicionais, são organizadas e têm como participantes, em sua maioria estudantes, tendo um caráter de confraternização, de forma de lazer e, até mesmo, de protesto. É de conhecimento popular que a cidade de Ouro Preto é Patrimônio Histórico Brasileiro e mesmo assim, não deixa de realizar festas e incentivar os estudantes, uma vez que a festa é uma forma de divulgação da cidade, por atrair turistas e gerar lucro para o município, além, de proporcionar diversão e lazer para todos os moradores da cidade.

Segundo Marcellino (1983; 1995), o equilíbrio entre as práticas no contexto do lazer é fundamental para as pessoas desenvolverem suas potencialidades. Para que isso ocorra, Largura (2000) aponta que as pessoas precisam ser educadas, necessitando de uma aprendizagem também do tempo livre e não só do trabalho, para que sejam estimuladas outras 
formas de raciocínio e de desenvolvimento social. Pode-se afirmar, então, que todos têm direito ao lazer, como possibilidade de melhora da interação pessoa-pessoa.

Essa aprendizagem é tida como mudança realizada por meio de experiências vividas e, dessa forma, pode ser estendida ao lazer, pois a aceitação e a importância de suas atividades dependem, em grande parte, da forma como interpretamos, vivenciamos e apreendemos suas definições e relações com o desenvolvimento, não só acadêmico, mas também universitário como um todo (MARTONI, SCHWARTZ, 2006).

Nesse sentido, é importante a reflexão sobre a vivência do lazer de estudantes universitários. Como se observa em Largura (2000) há, também, estudantes que trabalham durante o dia e estudam à noite, restando somente os finais de semana para o estudo e para o descanso e assim, existe uma tendência na comunidade universidade de que o lazer só se faz presente na vivência das pessoas que não trabalham nem estudam. É consensual que os estudantes trabalhadores são prejudicados pela não coincidência do período de férias do trabalho, com as férias do período escolar, prejudicando ainda mais tempo destinado ao lazer. Sem a opção de mudança na rotina diária, a falta de lazer pode ter conseqüências desastrosas na vida das pessoas em geral.

A fim de nortear as ações de intervalo social que possam auxiliar nas atividades que não sejam da rotina das pessoas, há as Políticas Públicas de Lazer, que são parâmetros no qual cada setor pode possuir uma política própria. É uma diretriz para a ação, feito pelo diálogo entre especialistas e a população, a qual orienta como o poder público irá atuar (PIMENTEL, 2003). Uma política deve possuir alguns quesitos, como: definição de pressupostos filosóficos e metodologia para a ação; fixação de prioridades, a partir da análise da realidade do lugar; aplicação do lazer enquanto instrumento de mobilização e participação da popular; geração contínua dos quadros de funcionários e dos multiplicadores dos projetos; criação e manutenção de espaços específicos para a prática do lazer; gerenciamento dos eventos e 
impacto (shows, festas, torneios); e interação com as demais políticas públicas setoriais (saúde, educação) e gerais.

Considerando a opinião da população sobre a festa e a Lei Seca, o presente artigo problematiza a questão do moralismo sobre o lazer, as políticas públicas e as relações de poder. Tem-se como questionamento de fundo se as pessoas são capazes de encontrar um modo para que as festas ocorram sem prejuízos para moradores ou estudantes. Para tanto, buscou percepções desses sujeitos sobre a lei seca, indagando se existem políticas públicas de lazer voltadas para os jovens.

\section{METODOLOGIA}

Essa é uma pesquisa de cunho descritivo exploratório (THOMAS; NELSON, 2002), que, dentro dos limites acadêmicos desse tipo de estudo, buscou delinear o cenário de uma população específica quanto ao problema da festa e da lei seca, visando subsidiar desdobramentos no conhecimento e intervenção sobre as políticas de lazer.

Essa pesquisa foi realizada com a população de diferentes grupos sociais da zona 7 da cidade de Maringá, que foi dividida em quatro setores, como ilustrado esquematicamente abaixo.

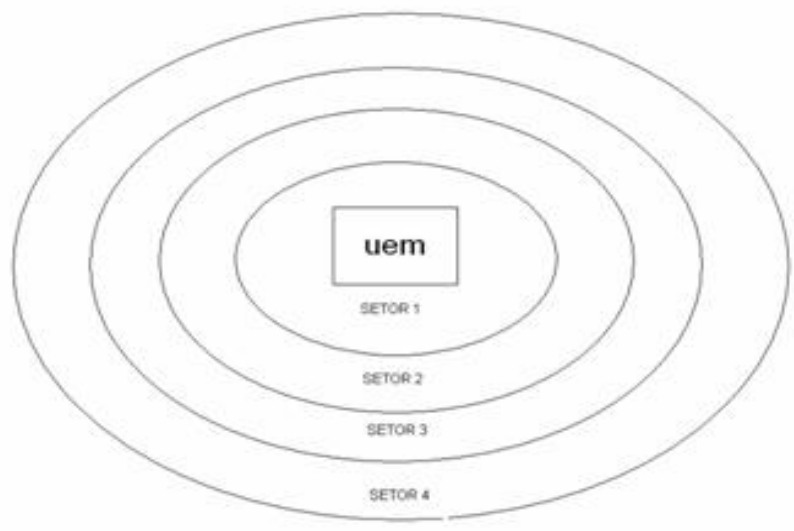

FIGURA.1: Esquema de estratificação espacial para organização da amostra. 
Cada setor se distancia entre quatro/cinco quadras do epicentro, a Universidade. A amostra foi dividida equitativamente por setor, englobando a Vila Esperança, o Jardim Universitário e a Região do Estádio Willie Davis, possuindo no total 23.671 mil habitantes, segundo o censo de 2001 (IBGE, 2008). O número de estudantes no município em ensino superior é de aproximadamente 57.815 mil universitários (IBGE, 2001). A pesquisa conta com uma amostra de cento e trinta e duas pessoas $(n=132)$, sendo sessenta e quatro $(n=64)$, universitários residentes na área delimitada e sessenta e oito $(n=68)$, sujeitos residentes nãoestudantes.

Segundo o Núcleo Regional de Ensino de Maringá, o bairro que possui a maior concentração de estudantes na cidade é o Jardim Alvorada e, em seguida, a Zona 7, mas, em se tratando de universitários, essa abriga o maior número.

Cada entrevistado discursou sobre o assunto, respondendo a um questionário semiestruturado. Portanto, não se induziu a resposta, de modo que cada pessoa desse a sua opinião sobre o assunto. Foi feita, também, a coleta de documentos referentes aos últimos vestibulares, para que fosse feita uma comparação entre as festas em vestibulares anteriores na UEM e em outras universidades, número de inscritos e desistências no vestibular, tendo fontes on-line, revistas, jornais, leis em rigor, entre outros.

A metodologia foi baseada em um estudo comparativo tendo algumas obras teóricas livros como base, comparando-as aos documentos do período e às entrevistas. Os dados foram tabulados e analisados em forma de gráficos, tendo como suporte seu contraste com os documentos recolhidos e bibliografia.

A pesquisa, aprovada pelo Comitê de Ética local, foi explicada aos participantes mostrando objetivos, metodologia, e justificativa -, os quais receberam um termo de consentimento esclarecido para participar dela e que foi assinado antes do início da pesquisa, para que os dados pudessem ser publicados. 
Flávia E. B. Lima, Luis M. Martins,

Lei Seca no Período do Vestibular e sua relação com as Políticas...

Marcelo K. de O. Sponchiado e Giuliano G. de A. Pimentel

\section{RESULTADO E DISCUSSÃO}

Os resultados obtidos estão apresentados na forma de gráficos, contendo o percentual das respostas válidas, sendo que cada gráfico será comentado. O GRAF. 1 e 2 dizem respeito às pessoas apoiarem ou não a existência da Lei Seca. Para tanto, os dados foram estratificados de forma a discriminar se os respondentes são estudantes da universidade ou estritamente moradores do entorno.

\section{Estudantes}

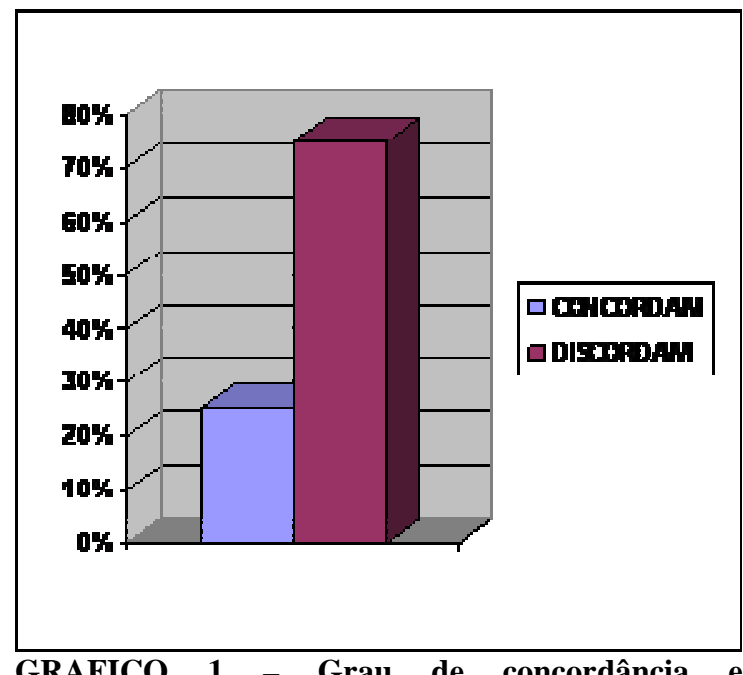

discordância dos estudantes com a lei seca.

\section{Moradores}

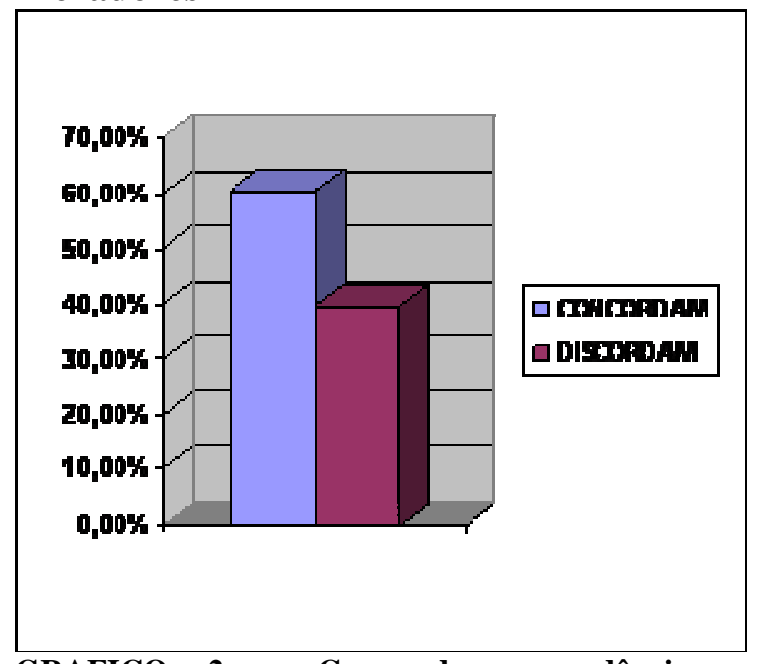

GRAFICO 2 - Grau de concordância e discordância dos moradores não estudantes com a lei seca. 
Flávia E. B. Lima, Luis M. Martins, Lei Seca no Período do Vestibular e sua relação com as Políticas... Marcelo K. de O. Sponchiado e Giuliano G. de A. Pimentel

O GRAF. 1 mostra a opinião sobre a Lei Seca dos Estudantes que moram ao redor da UEM e no gráfico 2, dos moradores não estudantes do bairro. Se fossem agregadas as respostas, $42,65 \%$ da amostra estariam a favor e 57,35\% contrários à lei seca. Separados os grupos, não surpreende que os estudantes sejam mais favoráveis à manutenção da festa enquanto os moradores menos favoráveis a ela. Mas não se pode deixar de ressaltar que, ao redor da UEM, a maioria dos moradores é universitária e deve-se levar em conta que essa lei prejudica os comerciantes do bairro e não contém os estudantes, pois esses vão para outros lugares beberem e se divertirem.

Assim, como confirma uma reportagem do jornal Gazeta do povo (2008)

A lei seca [...] durante o período de vestibular da instituição, não impediu que houvesse confusão entre estudantes e policiais na noite de domingo (6), primeiro dia do processo seletivo. Estudantes foram multados e seis veículos foram apreendidos e levados para a delegacia da cidade. Os jovens respeitaram a determinação e se concentraram no estacionamento do estádio Willie Davids, região da cidade onde a lei não impede o consumo de bebidas alcoólicas. No começo da noite, no entanto, policiais militares chegaram para acompanhar a diversão dos estudantes. A ação era contra os que estavam com o som do carro ligado, mas os PMs não permitiam que eles desligassem ou abaixassem o volume antes que a equipe da Polícia Ambiental chegasse para verificar a potência do som. 'Eles tiraram a chave do carro para a gente não poder desligar, porque eles queriam multar a gente de qualquer jeito', disse a estudante Marcela Peregrino ao telejornal Bom Dia Paraná.

Alguns moradores do bairro que não são estudantes deram entrevistas para o mesmo jornal e esclareceram que a festa que os estudantes estavam fazendo no local não os estava incomodando. Já outros reclamaram que não conseguiam dormir e que realmente o barulho incomodava, tanto que a informação que a Polícia Militar passou ao jornal foi a de que havia recebido vários telefonemas para o número de emergência 190, com reclamações sobre o barulho.

Para os estudantes freqüentadores dessas comemorações, que são barulhentas, efetivamente combatidas pela política, é contraditório observar a carência de policiamento no período das aulas. Isso porque há um índice significativo de assaltados 
Flávia E. B. Lima, Luis M. Martins, Lei Seca no Período do Vestibular e sua relação com as Políticas... Marcelo K. de O. Sponchiado e Giuliano G. de A. Pimentel

no bairro, como mostra o jornal local O Diário on-line (2008), ressaltando que a zona 7

é o segundo bairro onde mais ocorrem assaltos e violência, com 14,92\%, perdendo somente para o centro da cidade com $24,40 \%$ das ocorrências. Na fala noticiada de uma moradora: “[...] durante o ano inteiro, para nós, que estudamos aqui na UEM, não tem polícia para impedir estupro ou assalto. Mas no dia de vestibular eles chamam tropa de choque de outras cidades para impedir a gente de consumir cerveja", reclamou Marina Boury ao Bom Dia Paraná (PORTAL RPC, 2008). Há, ainda, uma página (http://angelorigon.blogspot.com/) de relacionamento na qual muitos estudantes relatam sobre os assaltos que sofrem.

O GRAF. 3 e 4 dizem respeito aos motivos pelos quais os estudantes moradores do bairro têm objeções ou concordam com a Lei Seca, respectivamente.

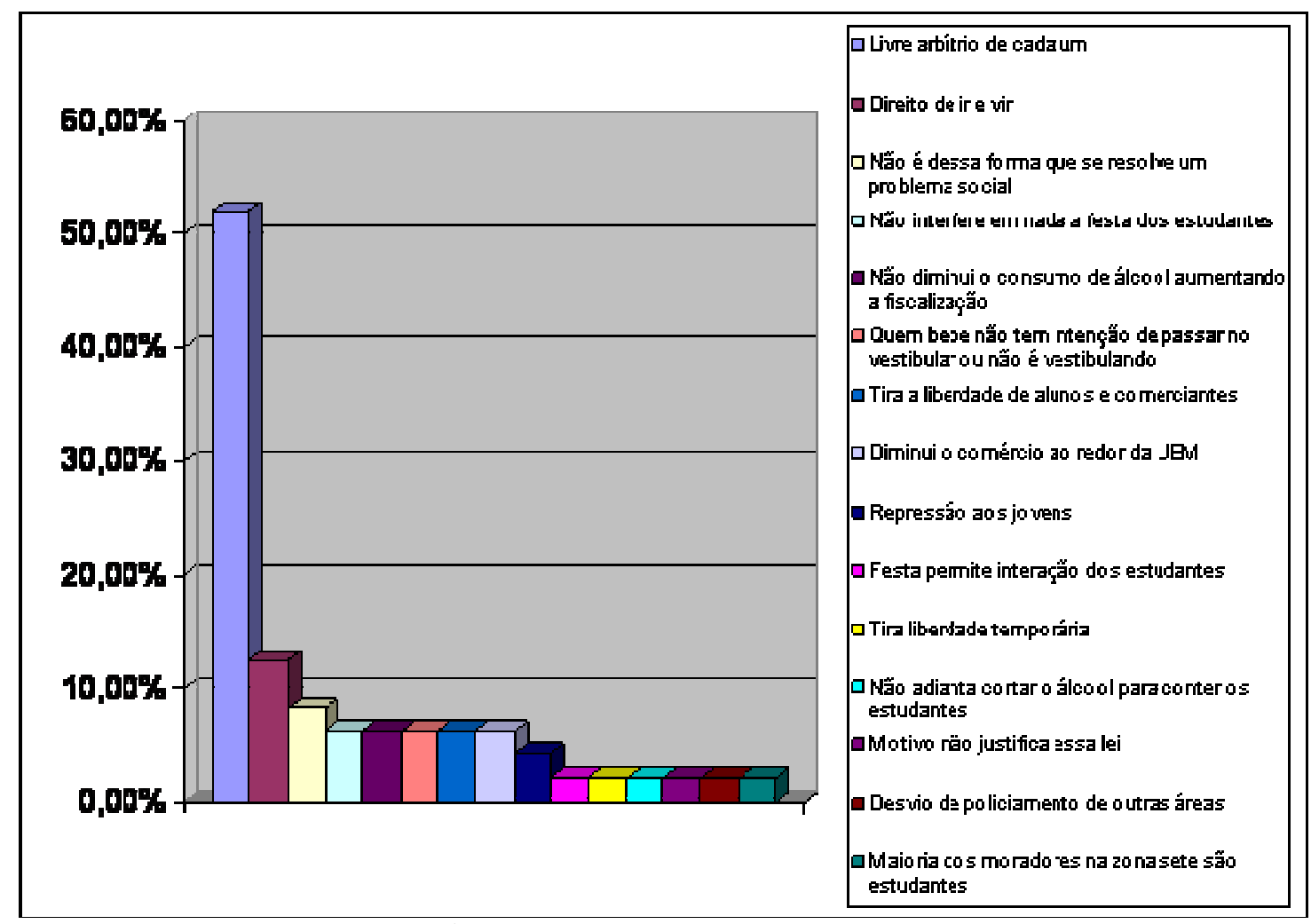

GRAFICO 3 - Principais objeções à Lei seca pelos estudantes. 
Flávia E. B. Lima, Luis M. Martins, Lei Seca no Período do Vestibular e sua relação com as Políticas... Marcelo K. de O. Sponchiado e Giuliano G. de A. Pimentel

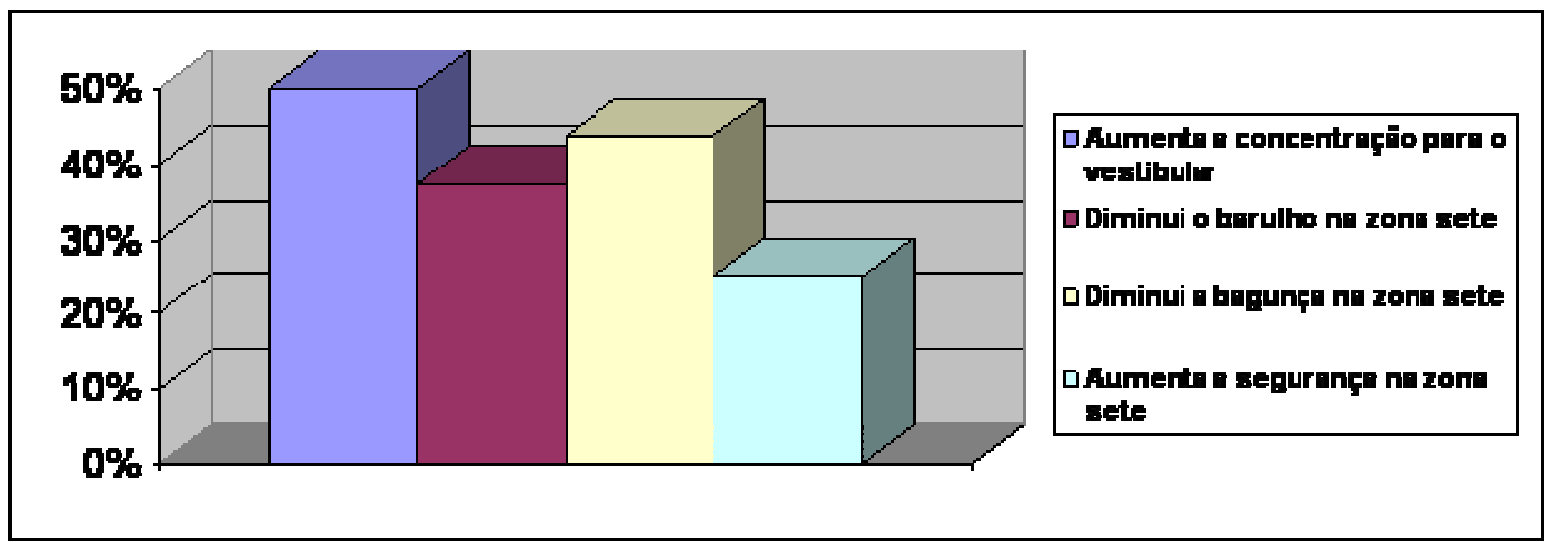

Gráfico 4 - Principais motivos pelos quais os estudantes concordam com a Lei seca.

No GRAF. 3, notar-se que os dois principais motivos pelos quais os estudantes têm objeções à leis são o exercício do livre arbítrio e do direito de ir e vir, cuja garantia vem prevista tanto na Constituição Federal Brasileira (1998), que assim dispõe:

Art. $5^{\circ}$ Todos são iguais perante a lei, sem distinção de qualquer natureza, garantindo-se aos brasileiros e aos estrangeiros residentes no País a inviolabilidade do direito à vida, à liberdade, à igualdade, à segurança e à propriedade, nos termos seguintes:

I - homens e mulheres são iguais em direitos e obrigações, nos termos desta Constituição;

III - ninguém será submetido a tortura nem a tratamento desumano ou degradante;

IV - é livre a manifestação do pensamento, sendo vedado o anonimato;

XIII - é livre o exercício de qualquer trabalho, ofício ou profissão, atendidas as qualificações profissionais que a lei estabelecer;

XVI - todos podem reunir-se pacificamente, sem armas, em locais abertos ao público, independentemente de autorização, desde que não frustrem outra reunião anteriormente convocada para o mesmo local, sendo apenas exigido prévio aviso à autoridade competente;

LIV - ninguém será privado da liberdade ou de seus bens sem o devido processo legal;

LXVIII - conceder-se-á "habeas-corpus" sempre que alguém sofrer ou se achar ameaçado de sofrer violência ou coação em sua liberdade de locomoção, por ilegalidade ou abuso de poder;

Segundo o Núcleo Regional de Ensino de Maringá, o bairro que tem maior concentração de estudantes na cidade é o Jardim Alvorada, e logo depois, a Zona 7, mas, em se tratando de universitários, a Zona 7 abriga o maior número, como dito 
Flávia E. B. Lima, Luis M. Martins, Lei Seca no Período do Vestibular e sua relação com as Políticas... Marcelo K. de O. Sponchiado e Giuliano G. de A. Pimentel

anteriormente. Assim, pode-se afirmar que o comércio do bairro está relacionado ao consumo dos estudantes.

Nas falas dos estudantes, pode-se notar, também, que a polícia tem abusado de seu poder e que a permanência dos jovens nas ruas está garantida por lei, pois todo cidadão possui o direito de ir e vir.

Já no GRAF. 4, no qual os estudantes concordam com a Lei Seca, um dos principais motivos alegado por eles é que ela possibilita aumentar a concentração no vestibular e diminuir a bagunça, sendo um motivo consequiência do outro, o que é uma realidade. Mas, segundo os próprios estudantes, quem está nas ruas fazendo festa não está prestando vestibular, mas sim são os discentes da universidade que estão em início de férias e em um momento de confraternização.

Já referente aos moradores não-estudantes, o GRAF. 5 e 6 mostram os motivos pelos quais os moradores da zona 7 têm objeções e concordam com a Lei Seca.

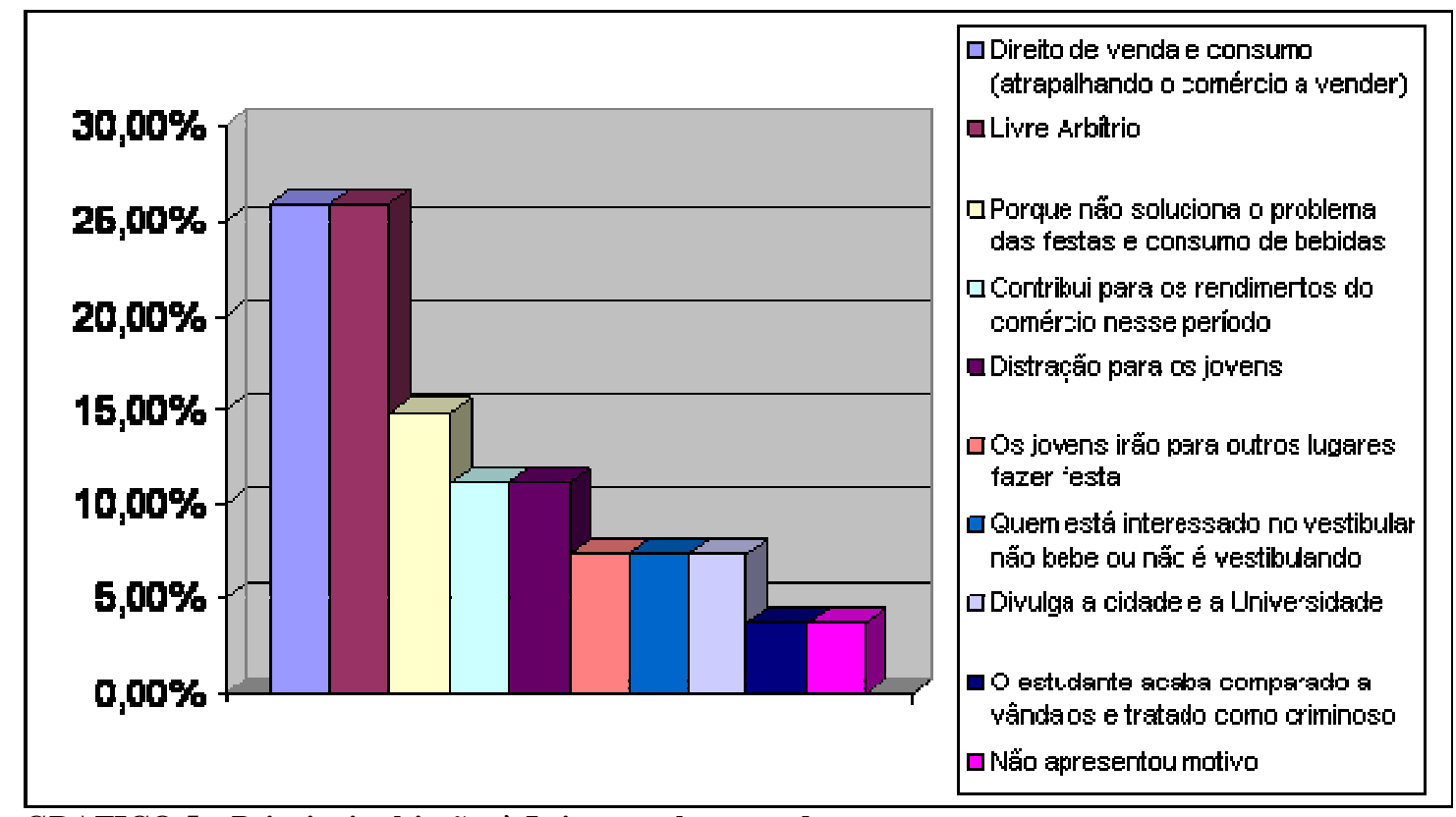

GRAFICO 5 - Principais objeções à Lei seca pelos moradores. 
Flávia E. B. Lima, Luis M. Martins, Lei Seca no Período do Vestibular e sua relação com as Políticas... Marcelo K. de O. Sponchiado e Giuliano G. de A. Pimentel

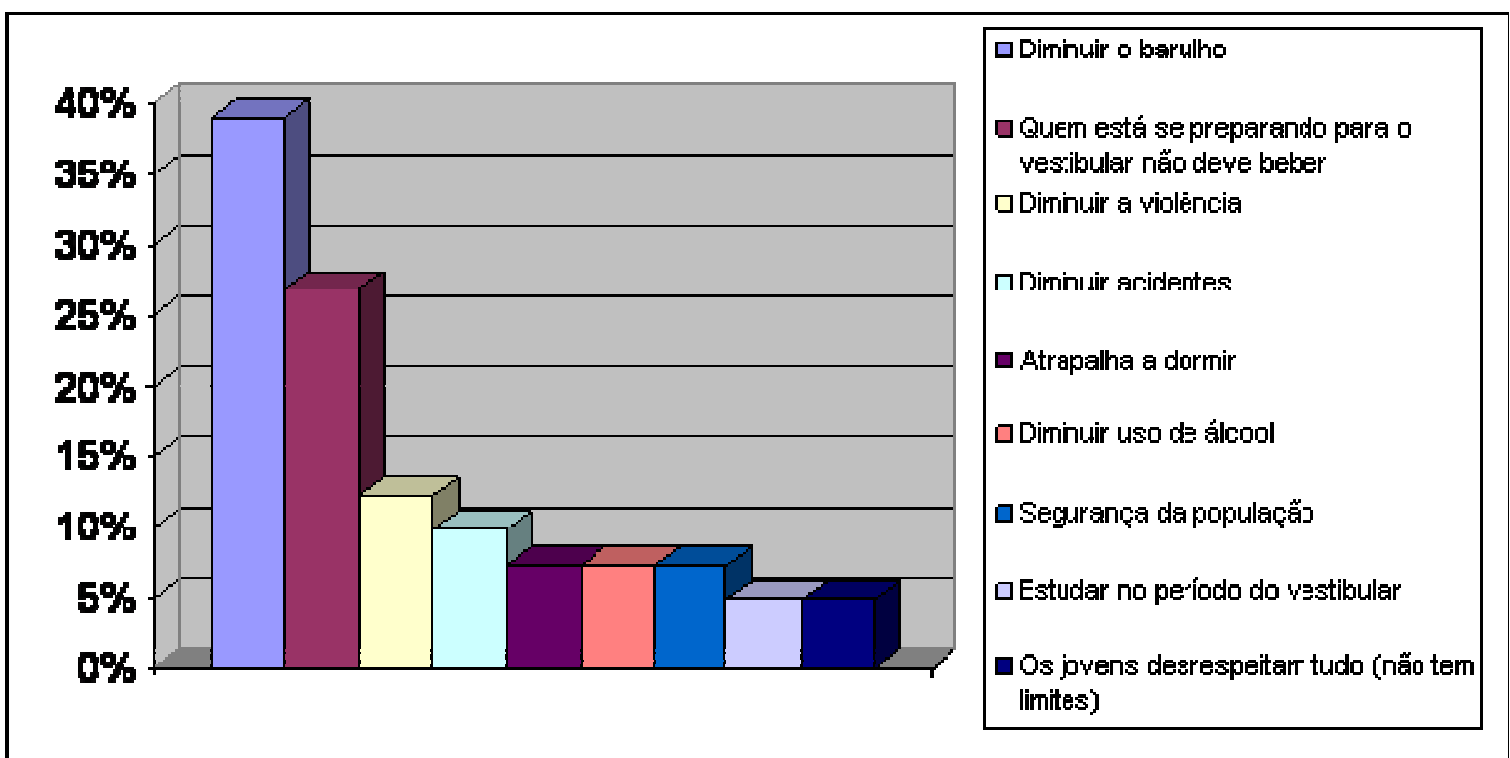

GRAFICO 6 - Principais motivos pelo quais os moradores não estudantes concordam com a Lei seca.

Analisando o GRAF. 5 e 6, obtêm-se a opinião dos moradores não-estudantes, nos quais também defendem alguns pontos de concordância e discordância com relação à Lei Seca. Os principais pontos em que eles discordam dela, mostrados no GRAF. 5, é o próprio livre arbítrio, já citado pelos estudantes, e o direito de venda e consumo dos comerciantes, o que também está descrito no Código do Consumidor (1990), pois os comerciantes têm direito de vender, por meio de um alvará e o pagamento impostos, o que assegura esse direito:

Código de Defesa do Consumidor, Lei No 8078/90, que foi criado para regulamentar as relações de consumo, entendidas essas como sendo o vinculo estabelecido entre fornecedor e consumidor, ligados por um objeto que será necessariamente, um serviço ou um produto. Esses três requisitos devem vir obrigatoriamente, coexistirem, sob pena de não se aplicar o Código de Defesa do Consumidor (1990) e, sim, o direito comum.

Uma moradora da zona 7, não-estudante, fez um comentário em um blog na internet (disponível em http://blogdoronaldo.wordpress.com/2008/04/02/barulho-naregiao-da-uem-2/) relatando sua opinião da criminalização das festas. A moradora diz:

Sou moradora recente de Maringá e da Zona 7 e, como venho de São Paulo - capital, não compreendo toda a polêmica em torno da suposta 
Flávia E. B. Lima, Luis M. Martins, Lei Seca no Período do Vestibular e sua relação com as Políticas... Marcelo K. de O. Sponchiado e Giuliano G. de A. Pimentel

confusão causada pelos estudantes da região aos finais de semana. De fato, as reivindicações do Centro Acadêmico da UEM são absurdas. Mas, de outro lado, a população de Maringá também faz queixas desproporcionais. Por que a polícia tem que agir contra o barulho? Não há um PSIU (Programa de Silêncio Urbano) na prefeitura? Não há criminalidade de fato na cidade a ser combatida, por isso é preciso inventar tarefas para os guardas? Sinceramente, não acho que o barulho causado pelos estudantes mereça tanto estardalhaço. É quase um lugar-comum tratar os estudantes como um estorvo - isso se vê na Zona 7 inteira, em qualquer dia da semana -, enquanto a população se esquece de que estes estudantes são parte da cidade, e da economia da cidade. Se a UEM fosse fechada, quantos estabelecimentos comerciais faliriam na cidade, ou eles não fariam diferença? Quantos maringaenses não deixariam de ter a renda dos aluguéis de quitinetes e apartamentos? Não seria muito cômodo para os habitantes da cidade que os estudantes simplesmente desaparecessem da cidade quando chegasse o final de semana, ou ao final das aulas? Maringá não é uma cidade pequena, é aliás muito maior do que eu esperava, quando cheguei aqui. Parece ingenuidade por parte de uma classe de moradores querer morar justamente nesta parte da cidade e não arcar com os incômodos que, mesmo não sendo tão grandes na minha opinião, são inevitáveis.

No entanto, alguns dos principais motivos pelos quais os moradores concordam

com a Lei Seca, mostrados no GRAF. 6, é para que haja diminuição da violência na

zona 7 , nos períodos de vestibular, pois esse número aumenta em razão de os estudantes exagerarem nas bebidas e drogas, aumentando o número de brigas. Outro ponto que eles alegam é que quem está se preparando para o vestibular não deve beber e sim, estudar e se concentrar para a prova.

Nessa linha de pensamento, Eduardo Ferreira (2008), militante político do partido Democratas, publicou em seu blog as seguintes ponderações:

Minha observação é a respeito da situação de constrangimento, falta de respeito e principalmente de segurança por que passa toda a população residente na Zona 07 e Jardim Universitário. São muitas famílias que perderam o direito de viver em paz devido ao vandalismo, ao tumulto, arruaças, ao barulho e tantos outros problemas causados por uma molecada mal educada, vândalos, bêbados, viciados, Patricinhas e Mauricinhos filhinhos de papai e mamãe que desfilam com seus carrões onde investiram uma grana preta em equipamento de som só para ver quem faz mais barulho. Para quem passar pelo local depois de determinada hora noturna, principalmente às noites de quinta-feira, é comum ver os arruaceiros fechando as ruas com seus carros, bebendo até cair em plena calçada, fumando maconha livremente, e gatões e gatinhas abaixando as calças 
Flávia E. B. Lima, Luis M. Martins, Lei Seca no Período do Vestibular e sua relação com as Políticas... Marcelo K. de O. Sponchiado e Giuliano G. de A. Pimentel

para fazer as necessidades (mijando e cagando) em plena rua e calçada. Desculpem o vocabulário, mas é exatamente o que acontece. Os moradores se tornaram reféns destes desocupados, que ainda ameaçam os moradores que tentarem qualquer ato para acabar com a bagunça. Estes moradores, senhores e senhoras pais de família, que precisam trabalhar para sustentar sua prole, por mais que procurem auxílio das autoridades, acabam sempre frustrados com uma zorra que parece não ter fim. É passada a hora das autoridades acabarem de vez com esta zona, esta zorra, este tormento [...]

Contrapondo isso, o síndico do Conjunto Habitacional Maringá, Hajime Oshita, diz que os estudantes realmente são responsáveis pela economia do bairro e que durante o período de férias, o comércio pára. O conjunto tem 460 apartamentos, divididos em 15 blocos. "São aproximadamente 2.200 pessoas morando no conjunto, é como se fosse uma cidadezinha", afirma Oshita. Cerca de $40 \%$ dos apartamentos são habitados por estudantes, mas o síndico diz que não é difícil a convivência com eles. "Eles são fáceis de lidar porque entendem tudo com um bom diálogo." (O DIÁRIO MARINGÁ, 2008).

O estudante Adriano Silva, que é morador do conjunto Maringá, diz acreditar que o fato de haver boa convivência entre estudantes e famílias é bom para ambos os lados. "Acredito que é até uma forma de equilíbrio. Se morasse só família, seria um lugar muito conservador. Se fossem só estudantes, muita bagunça. Assim equilibra", conclui Silva. (O DIÁRIO MARINGÁ, 2008).

O GRAF. 7 e 8 mostram as melhores soluções apontadas e encontradas por estudantes e moradores para os dias de vestibular e em relação a Lei Seca nesse período: 
Flávia E. B. Lima, Luis M. Martins, Lei Seca no Período do Vestibular e sua relação com as Políticas... Marcelo K. de O. Sponchiado e Giuliano G. de A. Pimentel

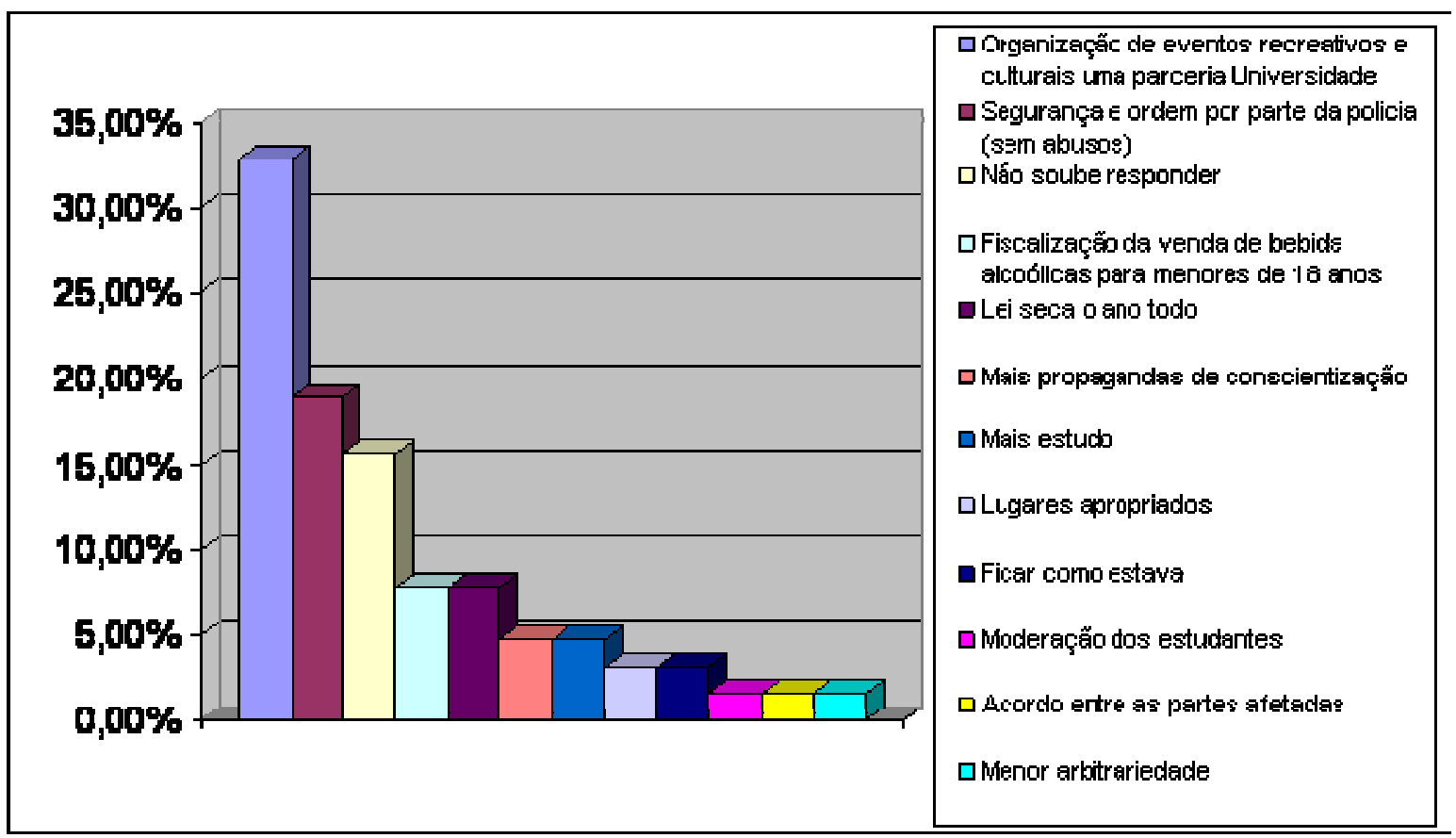

GRAFICO 7 - Soluções propostas pelos estudantes.

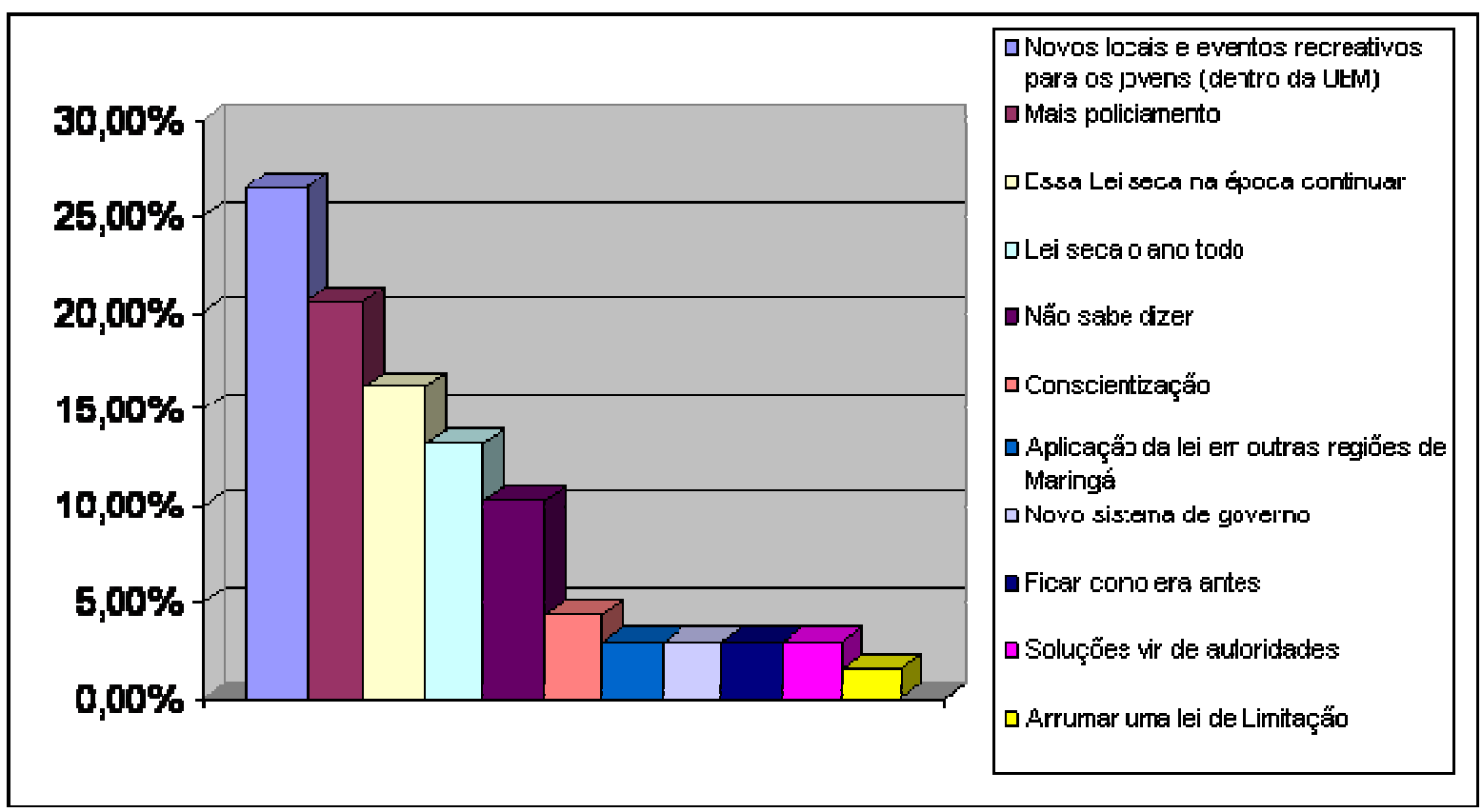

GRAFICO 8 - Soluções propostas pelos moradores não estudantes.

Analisando os dados do GRAF. 7 e 8, observa-se que o problema das festas mais apontado pelos estudantes e moradores é a falta de eventos voltados para os jovens, não só durante o vestibular, mas também no decorrer do período letivo. Os vestibulares coincidem com o término do semestre letivo e início de férias para os 
Flávia E. B. Lima, Luis M. Martins, Lei Seca no Período do Vestibular e sua relação com as Políticas... Marcelo K. de O. Sponchiado e Giuliano G. de A. Pimentel

universitários, e isso faz com eles fiquem mais exaltados, procurando algum tipo de lazer para comemorar as férias, e ainda, despedir-se dos amigos que moram em outras cidades. Apontando, de um modo geral, que a solução seria que a universidade, juntamente com órgãos públicos, deveria realizar uma política de lazer voltada para os jovens. E assim, nos dias de vestibular, organizar eventos que sejam interessantes para os universitários e vestibulandos, bem como para a população em geral, não prejudicando nenhum dos lados.

Para afirmar a não ocorrência de políticas públicas de lazer pode-se indicar um evento encerrado em 30 de abril de 2008, A $1^{\text {a }}$ Conferência Nacional de Juventude foi considerada um marco no esforço para consolidar a política nacional de juventude e incluir, de forma permanente, o tema na agenda das políticas públicas. Porém, entre todos os itens colocados como prioridades, somente um era relacionado com Políticas Públicas de Lazer voltadas para os jovens, colocando que se deve:

[...] ampliar e qualificar os programas e projetos de esporte, em todas as esferas públicas, enquanto políticas de Estado, tais como os programas Esporte e Lazer da Cidade, Bolsa Atleta e Segundo Tempo com núcleos nas escolas, universidades e comunidades, democratizando o acesso ao esporte e ao lazer a jovens, articulados com outros programas existentes.

Comprovando, assim, que essa política está defasada, ou mesmo escassa. A importância que o lazer vem ganhando nas últimas décadas, como problema social e como objeto de reivindicação, ligada à qualidade de vida nas cidades, não vem sendo acompanhada pela ação do poder público, com o estabelecimento de políticas setoriais, na área, devidamente articuladas com outras esferas de atuação, vinculadas com as iniciativas espontâneas da população e com parcerias junto à iniciativa privada (MARCELLINO, 1996). 
Flávia E. B. Lima, Luis M. Martins, Lei Seca no Período do Vestibular e sua relação com as Políticas... Marcelo K. de O. Sponchiado e Giuliano G. de A. Pimentel

\section{CONCLUSÃO}

A partir da voz dos moradores, a pesquisa nos mostrou uma deficiência de políticas públicas de lazer na cidade de Maringá e, sequer, de equipamentos específicos de lazer que favoreçam um lazer menos disfuncional.

Durante a juventude há uma busca mais efetiva por lazer, especialmente relacionado à sociabilidade e desafio dos limites, o que nem sempre representa atividades usuais ou regramento. Em complemento, o jovem brasileiro ressente-se de opções de lazer em seu tempo disponível. Para alguns, o maior atrativo são "barzinhos", festas, boates e outros locais propícios ao consumo exacerbado de drogas ilícitas e álcool.

Entretanto não se trata de promover uma leitura moralista do lazer vivenciado pelos jovens. O concreto da realidade aponta para investimentos das redes de sociabilidades, realizados na maior parte sob a forma de festas, que podem ser vistos como construções coletivas em prol do bem-comum. Logo, em termos aristotélicos, a festa dos estudantes é ética uma vez que visa o Bem do indivíduo e da polis, embora possamos ver limites políticos nessa forma de mobilização juvenil.

De outro lado, no campo da oferta de políticas públicas, as ações do governo municipal e da Universidade são tímidas carecendo de mais clareza nos parâmetros norteadores da ação. O que se verifica, na maioria das vezes, é uma mistura do preconceito, ainda existente em algumas áreas, com o imobilismo, muitas vezes mascarado de discursos até ditos "transformadores". A observação dos dados recolhidos mostrou que a instituição da Lei Seca no município se enquadra nessa análise, pois foi uma ação repressora sobre uma festa tradicional, gerida numa confluência de atores, que vão da efervescência estudantil até o interesse dos comerciantes.

Não se trata de ir contra o processo civilizatório e seu controle, por exemplo, do consumo de álcool e drogas ilícitas, como foi promulgada a lei nacional, a qual proíbe 
Flávia E. B. Lima, Luis M. Martins, Lei Seca no Período do Vestibular e sua relação com as Políticas... Marcelo K. de O. Sponchiado e Giuliano G. de A. Pimentel

beber e dirigir, mesmo sendo o mínimo, pois as pessoas poderão vir a sofrer menos acidentes, com a diminuição do índice de mortes, brigas e violência. Ocorre que a Lei seca nacional não desfez a liberdade para as pessoas beberem, freqüentarem bares. Apenas impediu que pessoas alcoolizadas dirigissem. No caso de Maringá foi proibida a venda de bebidas em um período conhecido por excessos e festividade. A proibição, além de ter caráter temporal, também tem caráter espacial, já que dirigida a uma única área da Cidade e não a ela toda - lembra-se do 'todos são iguais perante a lei'! Em certa analogia é como proibir o álcool no carnaval.

Se o lazer é direito do cidadão e o uso de bebidas lícitas também, por isonomia caberia à polícia, e as autoridades, de forma geral, controlar a venda de bebidas alcoólicas para menores de 18 anos, que é proibida constitucionalmente. O comércio deve seguir essa lei rigorosamente. Já a sociedade civil organizada e o poder público diante do conflito provocado pela festa, optaram pela repressão, algo eficiente em curto prazo. Porém, é essencial que o Estado se faça presente onde exista carência de políticas culturais, fazendo da motivação de vestibulandos e acadêmicos uma possibilidade de educação para o lazer.

Para ilustrar, como parte de Políticas Públicas de Lazer para os jovens, poderiam ser organizados eventos durante o final da tarde, dentro da universidade nos dias de vestibular, ou mesmo em outros períodos, sendo uma prática freqüente, para que houvesse uma interação entre os estudantes. Nesse evento poderia ser constituída uma programação, fruto de planejamento participativo, com música, prática esportiva, debates, mostra de filmes, teatro, feira de livros, visitas de vestibulandos ao campus, entre outros. Esse tipo de alternativa se assemelha ao comumente proposto por aqueles que pensam em contrapor-se ao trote violento nas universidades. Mas por que essas 
Flávia E. B. Lima, Luis M. Martins, Lei Seca no Período do Vestibular e sua relação com as Políticas... Marcelo K. de O. Sponchiado e Giuliano G. de A. Pimentel

iniciativas não são assumidas tão entusiasticamente quanto a adoção de proibições e violência?

O principal limite deste artigo é não encontrar resposta simples a esse questionamento, pois considerou apenas a opinião da população. $\mathrm{Na}$ verdade, muitos fatores articulam-se: lazer não é visto como prioridade de políticas, interesses de mercado, tradição moralista em reprimir manifestações lúdicas e populares, impotência do Estado em enfrentar as causas dos tumultos (daí a repressão aos sintomas). Vale lembrar que cabe às prefeituras, secretarias e aos órgãos públicos de administração geral a busca de soluções para realizar transformações e adaptações necessárias no espaço de lazer, de forma que a população seja envolvida no processo, que seja levada em conta a relação de apropriação que os cidadãos estabelecem com o espaço urbano como um todo e, mais especificamente, com o espaço de lazer (MARCELLINO, 1996). E para que isso se viabilize, é necessário trabalhar com estratégias de ação que privilegiem a participação da população.

Essa alternativa, em qualquer área do social onde seja desenvolvida, leva em conta a necessidade do conhecimento da situação, ou seja, da realidade, interesses e aspirações de determinada clientela; sua participação efetiva no planejamento, organização e avaliação das ações, e a integração com órgãos e instituições locais, seja em busca de apoio político, ou de para manutenção e ampliação da ação (MARCELLINO, 1996). Porém, se evidenciou o imediatismo da lei, contrastando com uma série de alternativas sugeridas pelos moradores envolvidos, sugerindo que a opinião da população não é valorizada como um marco introdutório (embora insuficiente) para resolução de problemas.

Assim, pode-se dizer que as medidas da Lei Seca se mostram insuficientes, pois camuflam as deficientes políticas públicas de lazer, mostrando um Estado que interfere 
Flávia E. B. Lima, Luis M. Martins, Lei Seca no Período do Vestibular e sua relação com as Políticas... Marcelo K. de O. Sponchiado e Giuliano G. de A. Pimentel

pautado no casuísmo. Por esta lógica, a Lei Seca, embora equivocada, não é o problema, pois se baseia no direito do descanso (um componente do lazer) de uma parcela de moradores do entorno do campus. Buscou-se a maneira mais fácil, rápida e economicamente mais viável de acabar com os conflitos do bairro, já que a melhoria das Políticas Públicas de Lazer demanda tempo e maiores recursos financeiros. Mas, como a história ensina, quando se parte do imediatismo para buscar soluções rápidas para os problemas sociais, apenas se alimenta um problema maior à frente.

\section{REFERÊNCIAS}

ACIM. Vestibular de Inverno da UEM registra 6,32\% de faltas. Maringá, 2008. Disponível em: http://www.acim.com.br/?see=ver_noticias_locais\&codigo=3715. Acesso em: 22 jul. 2008.

ASSIS, Chiquinho de. Carnaval de Ouro Preto: muitas histórias, poucos locais. Ouro Preto, s/d. Disponível em: http://www.ouropreto.com.br/artigos/detalhe.php?idartigo=21. Acesso em: $05 \mathrm{dez}$. 2008.

BRASIL. Código de Proteção e Defesa do Consumidor. Lei n. 8078/90 de 11 de setembro de 1990.

BRASIL. Constituição (1988). Brasília: Senado Federal, Centro Gráfico, 1988, 292p.

CARVALHO, João Eloir (Org). Lazer no espaço urbano: Transversalidade e Novas Tecnologias. Curitiba: Champagnat, 2006.

FERREIRA, Eduardo. Trabalho, Ética e Cidadania. Maringá, 2008. Disponível em: http://eduardoferreira.wordpress.com/category/maringa/. Acesso em: 22 jul. 2008.

FERREIRA, Maria Nazareth. As festas populares na expansão do turismo: a experiência italiana. São Paulo: Arte \& Ciências, 2001.

GAZETA DO POVO. Mesmo com "lei seca", primeiro dia de vestibular da UEM tem confusão entre PMs e estudantes. Maringá, 2008. Disponível em: $<$ http://portal.rpc.com.br/gazetadopovo/vidaecidadania/conteudo.phtml?tl=1\&id=78425 2\&tit=Mesmo-com-lei-seca-primeiro-dia-de-vestibular-da-UEM-tem-confusao-entrePMs-e-estudantes>. Acesso em: 22 jul. 2008.

IBGE. Instituto Brasileiro de Geografia e Estatística. Disponível em: < http://www.ibge.gov.br/home/presidencia/noticias/noticia_visualiza.php?id_noticia=438 \&id_pagina=1>. Acesso em: 22 jul. 2008. 
Flávia E. B. Lima, Luis M. Martins, Lei Seca no Período do Vestibular e sua relação com as Políticas... Marcelo K. de O. Sponchiado e Giuliano G. de A. Pimentel

LARGURA, W. A. N. Fontes de lazer em estudantes de psicologia noturno. PSICOUSF, v.5, p. 73-85, 2000.

LEITE, C.B. O século do lazer. São Paulo: LTr, 1995.

LIMA, Helena Maria de Lisandra Morais de. O Auto da Liberdade: Manifestação de Lazer e Cultura em Mossoró/RN. In: BARBOSA, Andréia Dantas et al. Turismo cultura, lazer e possibilidades de intervenções. Natal: Banco do Nordeste, 2004. p. 87-102.

LUZ, F. O fenômeno urbano numa zona pioneira: Maringá. Maringá: Prefeitura, 1997.

MAIA, Lerson Fernando dos Santos; OLIVEIRA, Marcus Vinícius de Faria; LIMA, Dália Maria Maia Cavalcanti (Org.). Políticas de lazer e suas múltiplas interfaces no cotidiano urbano. Natal: CEFET, 2007.

MARCELLINO, N. C. Lazer e educação. Campinas: Papirus, 1995.

(Org.). Políticas públicas setoriais de lazer. O Papel das Prefeituras. Campinas, Autores Associados, 1996.

. Lazer e humanização. Campinas - SP: Papirus, 1983.

MARTONI, F. ; SCHWARTZ, G. M. . O Lazer na vida do estudante universitário. Lecturas educacion fisica y deportes (Buenos Aires), Buenos Aires, v. 97, n. 1, p. 1-6, 206.

MOESCH, Marutschka. Turismo e lazer: conteúdos de uma única questão. In: Marcellino, Nelson Carvalho (Org.). Formação e desenvolvimento de pessoal em lazer e esporte. Campinas: Papirus, 2003.

MOTA, Adeir Archanjo da. A cidade de Maringá e as instituições de ensino superior: novos espaços de concentração e exclusão. Acta Sci. Human Soc. Sci. Maringá, v. 28, n. 2, 2 p. 2006. Disponível em: <http://www.periodicos.uem.br/ojs/index.php/ActaSciHumanSocSci/article/viewFile/15 6/79>. Acesso em: 22 jul. 2008.

MÜLLER, Ademir; DaCOSTA, Lamartine Pereira (Org.). Lazer e desenvolvimento regional. Santa Cruz do Sul: EDUNISC, 2002.

O DIÁRIO MARINGÁ - On-line. Lei Seca no vestibular da UEM. Disponível em: <www.odiariomaringa.com.br/noticia/194633>. Acesso em: 22 jul. 2008.

PASTORAL DA JUVENTUDE. $\mathbf{1}^{\text {a }}$ Conferência Nacional da Juventude. Disponível em: $\quad<$ http://www.pjmaringa.com.br/interativos/noticias/0805/080512ConferenciaNacionaldaJuventudedefiniuprioridades.htm>. Acesso em: 06 nov. 2008.

PEREIRA, Cláudio Manuel et al. Revista Contemporâneos. Viçosa: Departamento de Artes e Humanidades da UFV, mai-out 2008, n. 2. Disponível em: 
Flávia E. B. Lima, Luis M. Martins, Lei Seca no Período do Vestibular e sua relação com as Políticas... Marcelo K. de O. Sponchiado e Giuliano G. de A. Pimentel

<http://www.revistacontemporaneos.com.br/n2/pdf/vovos.pdf>. Acesso em: $04 \mathrm{dez}$. 2008.

PIMENTEL, Giuliano. Lazer: Fundamentos, Estratégias e Atuação Profissional. Jundiaí: Fontoura, 2003.

PORTAL RPC. Maringá tenta lei seca contra tumulto na UEM. Disponível em: < http://portal.rpc.com.br/gazetadopovo/vidaecidadania/conteudo.phtml?tl=1\&id=780476 \&tit=Maringa-tenta-lei-seca-contra-tumulto-na-UEM>. Acesso em: 06 nov. 2008.

PREFEITURA MUNICIPAL DE MARINGÁ. Diário Oficial. 2008.

ROLNIK, Raquel. O que é cidade. São Paulo: Brasiliense, 2004.

ROSA, Maria Cristina (Org.). "Festar na cultura". In: Festa, lazer e cultura. Campinas: Papirus, 2002. cap. 1, p. 11-41.

SANTINI, R.C. Dimensões do lazer e recreação - Questões espaciais, sociais e psicológicas. São Paulo: Angelotti, 1993.

SCALIANTE, Wil. Seria o fim do espírito universitário na zona 7?. Acorda Maringá: Maringá, 2007. Disponível em: <http://acordamaringa.blogspot.com/2007/11/seria-ofim-do-esprito-universitrio-na.html>. Acesso em: 22 jul. 2008.

SOUZA, Dulce Honorata de et al. O Lazer, a Cidade de Viçosa/MG e a Festa da República "Os Largados" algumas relações. In: SEMINÁRIO O LAZER EM DEBATE, 4. Coletânea... Belo Horizonte: UFMG, 2005. p. 210-218.

SUMA ECONÔMICA. Previsões de longo prazo: 2004 a 2010. São Paulo, janeiro 2004. p. 14-19.

THOMAS, J. R.; NELSON, J. K. Métodos de pesquisa em atividade física. 3. ed. Porto Alegre: Artmed, 2002.

\section{Endereço dos Autores:}

Flávia Évelin Bandeira Lima

Rua Mato Grosso, 2832

Campo Mourão-PR

Cep: 87303-160

Endereço Eletrônico: flaviaeblima@ hotmail.com

Luis Miguel Martins

Endereço Eletrônico: tato personal@ hotmail.com

Marcelo Kuhne de Oliveira Sponchiado

Endereço Eletrônico: marcelo.tennis@ hotmail.com 
Flávia E. B. Lima, Luis M. Martins, Lei Seca no Período do Vestibular e sua relação com as Políticas... Marcelo K. de O. Sponchiado e Giuliano G. de A. Pimentel

Giuliano Gomes de Assis Pimentel

Departamento de Educação Física (DEF)

Avenida Colombo, 5.790 - Campus Universitário

CEP 87.020-900 Maringá-PR -

Endereço Eletrônico: ggapimentel@uem.br 